\title{
ISOLATION AND IDENTIFICATION OF YEASTS FROM INDOOR SWIMMING POOLS IN DUHOK CITY WITH SPECIAL CONCERN TO THE EFFECT OF SOME DISINFECTANT AGENTS
}

\author{
Berivan A. Abdullah*, and Asia A.M.Saadullah
}

Dept. of Biology, College of Science, University of Duhok, Duhok, Kurdistan Region, Iraq

\begin{abstract}
:
The present study was conducted to study the level of yeast contamination in indoor public swimming pools in Duhok city. A total of 230 samples ( 50 water sample) were taken from swimming pool water and (180 swab samples) were taken from walls, flour of bathrooms, dressing rooms and flour around the pool in five indoor public swimming pools from September 2014 to February 2015. All samples were examined for the presence of yeasts using three culture media (Potato Dextrose Agar, Malt Extract Agar and Sabouraud's Dextrose Agar). The highest number of Yeast genera was in November (6) followed by October (5), December and January (4) while the lowest number was in September (3). Eleven (11) isolates yeasts were selected randomly for in vitro sensitivity to the disinfectant agents \{Chlorine, Chloroxylenol and Hydrogen peroxide $\left(\mathrm{H}_{2} \mathrm{O}_{2}\right)$ \}. All tested isolates were highly sensitive to chlorine, Chloroxylenol and $\mathrm{H}_{2} \mathrm{O}_{2}$. The MIC value of chlorine for most of them was $0.01 \%$ and for Chloroxylenol was $0.1 \%$ except Candida tropicalis and C. glabrata. Regarding the effect of $\mathrm{H}_{2} \mathrm{O}_{2}$ the $\mathrm{MIC}$ value ranged from $0.1 \%-12.8 \%$.
\end{abstract}

KEYWORDS: Isolation, Yeast, Duhok City, Chlorine, Chloroxylenol.

\section{INTERODCUTION}

Yeasts are single celled microorganisms they reproduce by the asexual process of budding or fission. They are ubiquitous and exist as saprobes, mutualisms or parasites in their life styles. (Hawksworth, 1991; Cannon and Hawksworth, 1995).

Swimming considered as one of the most popular sport for both young and old people of both sexes. It has many physical and mental benefits, it is advised as the most appropriate way to keep fit, stay healthy, having fun and for social life.

Numerous infectious agents of bacteria, fungi, viruses and protozoa may be brought into a pool from the bather's skin, in their saliva, urine, feces, also from dust, bird droppings and soil carried on bather's feet, which threatens the health of pool users. Fungi including yeasts grow very easily in damp and wet conditions inducing acute health effects (Robins and Morell, 2007). In recent years the resistance of yeasts toward many disinfectant agents has been increased dramatically, this problem derives the important current role of the in vitro disinfectant susceptibility testing to determine which agents are effective for a given infection. Disinfectants are chemical compounds commonly added to water and other domestic activities such as toilet and general house cleaning; they are used to control or reduce the growth of pathogenic microbes (Fraise, 2002). The aim of study is to determine the level of yeast contamination and the effect of some disinfectant agents on some yeast isolates in public swimming pools in Duhok city, Kurdistan Region of Iraq.

\section{MATERIALS AND METHODS}

\subsection{Sample Collection}

Fifty water samples and 180 indoor samples were collected from five indoor public swimming pools in Duhok city, Kurdistan Region of Iraq from September 2014 to January 2015. Sampling was carried out twice per month for each swimming pool. Water samples were collected in sterilized bottles and $1 \mathrm{ml}$ of Sodium thiosulfate was added to neutralize the chlorine residual in each sample (Bello et al., 2012). Indoor samples from bathrooms, dressing rooms, dried sauna rooms, walls and floor around the pools were taken using sterile cotton swabs. All samples were transferred immediately to the Faculty of Science/ Mycological Research Laboratory and were processed immediately upon arrival.

2.2 Isolation of yeasts from water samples by pouring method:

In this method $1 \mathrm{ml}$ of each water sample was added to six empty petridishes: three for Potato Dextrose Agar (PDA), two for Malt Extract Agar (MEA) and one for (SDA) and poured with $20 \mathrm{ml}$ of specified type of molten culture media. Then the plates (3PDA, 1MEA) were shaken gently and incubated at $25^{\circ} \mathrm{C}$ for $5-7$ days and the (1 SDA, 1 MEA) plates were incubated at $37^{\circ} \mathrm{C}$ for 1 week, and they were checked at frequent intervals.

2.3 Isolation of yeasts from indoor samples by Swab method:

The spreading method was used for isolating fungi from indoor environments according to the method described by Viegas et al., (2011). Each swab was spread over six petridishes containing three types of culture media (PDA, SDA and MEA). Three plates

\footnotetext{
* Corresponding author
} 
of PDA and one of MEA were incubated at $25^{\circ} \mathrm{C}$ for $5-7$ days; whereas the plates of SDA and MEA were incubated at $37^{\circ} \mathrm{C}$ for 1 week and were checked at frequent intervals.

\subsection{Yeasts Identification}

Identification for yeast species other than Candida was done by colony characterization and microscopic examination according to the keys and descriptions provided by de Hoog and Guarro, (1995), Ellis et al., (2007), Larone, (2011).

\subsection{Identification of Candida species}

2.5.1 Chromogenic Candida Agar (Rapid Labs Ltd., Essex, UK): Clinically important Candida species is identified using this selective medium which contains Chromogenic substrates that detect specific enzymes of some Candida species. This selective medium is light sensitive and prepared by dissolving $45.5 \mathrm{~g}$ of it in 1 Liter of distilled water; stirred until completely dissolved then autoclaved at $121^{\circ} \mathrm{C}$ for 15 minutes and poured in Petridishes and kept in refrigerator. The color of Candida sp. colonies grown on chromogenic Candida agar are shown below:

1. Candida albicans: emerald with metallic shine color.

2. Candida dubliensis: dark green color.

3. Candida krusei: light pink color.

4. Candida tropicalis: red purple color.

5. Candida glabrata: shiny white color.

\subsection{Disinfectant agents Sensitivity Test:}

2.6.1 Yeast Isolates: Eleven (11) yeast isolates were tested for Disinfectants sensitivity test, each isolate was subcultured before testing in a Sabouraud's Dextrose broth and incubated at $37^{\circ} \mathrm{C}$ for $24-48 \mathrm{hr}$.

2.6.2 Media: Yeast isolates were cultured on a Sabouraud's Dextrose Agar (SDA) medium for the Disinfectants sensitivity test. The SDA ((Lab M limited Co. UK) was prepared by dissolving $65 \mathrm{~g}$ in 1 liter of D.W., stirred until it completely dissolved and was then autoclaved at $121^{\circ} \mathrm{C}$ for $15 \mathrm{~min}$. and then poured onto petridishes.

2.6.3 Disinfectant Agents: Three commonly used disinfectants agents were chosen, namely:

1- Chlorine (BKG water solution company, Germany), with the following dilutions: $0.01,0.04,0.08,0.16,0.32$, and 0.64 $\%$.

2- Hydrogen peroxide (H2O2), (30\%, M.W 34.01, Alpha chemika, Mumbai, India), with the following dilutions: 0.1, $0.4,0.8,1.6,3.2$, and $12.8 \%$.

3- Chloroxylenol (Dettol), $(4.85 \%$ w/w, Green Planet Industries, United Arab Emirates), with the following dilutions: $0.025,0.1,0.2,0.4,0.8$, and $3.2 \%$.

\subsection{Susceptibility Test (method):}

2.7.1 Well Diffusion Method: Disinfectant agent's sensitivity test was performed using the well diffusion method which is simple, inexpensive and easy to read (Magaldi et al., 2004). For each yeast isolate, 6 plates of SDA were used. $0.1 \mathrm{ml}$ of yeast isolate was spreaded over 6 SDA plates using a sterile cotton swab. For each plate, 3 wells $6 \mathrm{~mm}$ in diameter were cut out of the agar using cork borer and filled with $0.15 \mathrm{ml}$ of the desired disinfectant agents, and incubated at $37^{\circ} \mathrm{C}$ for $24-48 \mathrm{hr}$.

\section{RESULTS AND DISCUSSION}

\subsection{Yeasts Genera Associated with Indoor Swimming Pools}

Table 1 represents the Yeasts genera isolated during five months of the study, the highest number of Yeast genera was in November (6) followed by October (5), December and January (4) while the lowest number was in September (3).

Candida species were also isolated from water of swimming pools in other countries such as Greece, Nigeria and Iran (Papadopulou et al., 2008; Itah and Ekpomhok, 2004; Azizi-far et al., 2006). Candida species are true opportunistic pathogen which constitutes the normal flora of the skin, oral cavity, gastrointestinal tract, virginal and the urinary tract of humans. They are inhabiting different environments particularly in water and soil (Ellis, 1994). Species of Candida are important opportunistic pathogens especially in immunocompromized individuals. Candida is the cause of candidiasis involving any part of the body; mucocutaneous, viginitis, bronchial and pulmonary paronchia and onychomycosis (Aronson and Soltani, 1976). Rhodotorula sp. isolated during this study commonly known as contaminants, but in recent years they have increasingly regarded as agents of severe infection. Aurobasidium sp. known as black yeast is ubiquitous in different environments such as water, air and soil. It causes allergy after exposure via humidity and the condition is characterized by cough, fever and chest infiltrates. Geotrichum sp. was found as normal flora in human and seems to cause diseases only in severely compromised hosts. Trichosporon sp. has been increasingly involved in disseminated diseases and related with infections in debilitated hosts (Odd, 1988).

Most of the above Yeasts (Candida, Rhodotorula, Geotrichum and Trichosporon) have previously been reported from swimming pools (Hosinzadeh et al., 2013; Viegas et al., 2010; Mohammed and Habeb, 2014; Nanbakhsh et al., 2004). Isolation of these Yeasts might due to continuous contamination of the swimming pool water by fungi through air, soil and human bodies. Opportunistic pathogenic Yeasts Candida, Rhodotorula and Trichosporon are abundant in the air and have been isolated from different locations because they reproduce by fragmentation and distribute in air (Aidoo et al., 1995).

Table 1. Distribution of Yeasts during different months of Year.

\begin{tabular}{rllllll}
\hline No. & Yeast isolates & Sep. & Oct. & Nov. & Dec. & Jan. \\
\hline 1. & Aurobasidium sp. & + & + & + & + & + \\
\hline 2. & Candida sp. & + & + & + & + & + \\
\hline 3. & Geotrichum sp. & - & + & + & - & - \\
\hline 4. & Rhodotorula sp. & - & + & + & + & + \\
\hline 5. & Trichosporon sp. & - & - & + & + & - \\
\hline 6. & Yeasts (non-identified) & + & + & + & + & + \\
\hline Total & 3 & 5 & 6 & 4 & 4 \\
\hline
\end{tabular}




\subsection{Disinfectants agents Susceptibility Test:}

3.2.1 Chlorine: Table 2 shows the result of susceptibility testing of Yeasts against the disinfectant chlorine. The results indicated that all isolates of Candida sp., Geotrichum sp. and Rhodotorula sp. were highly sensitive to chlorine. The MIC value for all tested strains was $0.01 \%$ except for Geotrichum sp. was $0.08 \%$. No resistance was observed among the tested strains. These results are in line with Bianchi et al., (1989), who found that two chlorine derivatives were active against the Aspergillus and Candida species tested.

\begin{tabular}{lccc}
\multicolumn{4}{c}{ Table 2. MIC of Chlorine against yeasts. } \\
\cline { 3 - 4 } No. & Fungal isolates & MIC (\%) & $\begin{array}{c}\text { No. of strain } \\
\text { inhibited }\end{array}$ \\
\hline 1. & Candida albicans (2) & 0.01 & 2 \\
\hline 2. & C. tropicalis(2) & 0.01 & 2 \\
\hline 3. & C. krusei (2) & 0.01 & 2 \\
\hline 4. & C. glabrata(2) & 0.01 & 2 \\
\hline 5. & Geotrichum sp. (1) & 0.08 & 1 \\
\hline 6. & Rhodotorula sp. (2) & 0.01 & 2 \\
\hline
\end{tabular}

3.2.2 Chloroxylenol: Table 3 shows the result of in vitro susceptibility testing of Chloroxylenol against yeasts isolates. Chloroxylenol (4chloro 3, 5-dimethyphenol) (Detol) is a broad spectrum antimicrobial chemical compound used to control fungi, bacteria, algae and viruses. It is not significantly toxic to humans. All tested yeasts showed high sensitivity to this disinfectant. According to the in vitro results of dettol on Yeasts, the results revealed that the concentration of $0.1 \%$ was the MIC for all isolates except for Candida tropicalis the MIC was $0.025 \%$. This result was in line with (Atayese et al., 2010) who studied the effect of dettol on Candida albicans and non albicans species.

Table 3. MIC of Chloroxylenol against yeasts.

\begin{tabular}{lccc} 
& & \multicolumn{2}{c}{ Chloroxylenol } \\
\hline No. & Yeasts isolates & $\begin{array}{c}\text { MIC } \\
(\%)\end{array}$ & $\begin{array}{c}\text { No. of strain } \\
\text { inhibited }\end{array}$ \\
\hline 1. & Candida albicans (2) & 0.1 & 2 \\
\hline 2. & C. tropicalis(2) & 0.025 & 2 \\
\hline 3. & C. krusei (2) & 0.1 & 2 \\
\hline 4. & C. glabrata(2) & 0.2 & 2 \\
\hline 5. & Geotrichum sp. (1) & 0.1 & 1 \\
\hline 6. & Rhodotorula sp. (2) & 0.1 & 2 \\
\hline
\end{tabular}

3.2.3 Hydrogen Peroxides: Table 4 shows the results of in vitro susceptibility testing of Hydrogen peroxides against yeasts isolates. Hydrogen peroxide ( $\left.\mathrm{H}_{2} \mathrm{O} 2\right)$ is bleach and an oxidizing agent that is active against a variety of microorganisms. At low concentrations, it has a variety of medicinal and domestic uses; at higher concentrations it has many commercial and industrial uses. It is also used for foot and toenail fungus infection (onychomycosis).

Regarding the effect of hydrogen peroxide on yeasts, all isolates were sensitive with different MIC values. Candida albicans was more sensitive than others and has MIC value $0.1 \%$, Candida tropicalis and Rhodotorula sp. have MIC value $0.4 \%$ while for Candida glabrata it was $0.8 \%$. Geotrichum $s p$. had MIC value $3.2 \%$. Candida krusei was more resistant than other and had MIC value of $12.8 \%$.

Table 4. MIC of Hydrogen peroxides against yeasts.

\begin{tabular}{lccc} 
& & \multicolumn{2}{c}{$\mathrm{H}_{2} \mathrm{O}_{2}$} \\
\hline No. & Yeasts isolates & $\begin{array}{c}\text { MIC } \\
(\%)\end{array}$ & $\begin{array}{c}\text { No. of strain } \\
\text { inhibited }\end{array}$ \\
\hline 1. & Candida albicans (2) & 0.1 & 2 \\
\hline 2. & C. tropicalis(2) & 0.4 & 2 \\
\hline 3. & C. krusei (2) & 12.8 & 1 \\
\hline 4. & C. glabrata(2) & 0.8 & 2 \\
\hline 5. & Geotrichum sp. (1) & 3.2 & 1 \\
\hline 6. & Rhodotorula sp. (2) & 0.4 & 2 \\
\hline
\end{tabular}

\section{CONCLUSION}

It is concluded from the present study that:

1. Indoor public swimming pools are suitable environments for hosting numerous potentially pathogenic yeasts.

2. Yeasts are highly sensitive to disinfectant agents used.

\section{REFERENCES}

Aidoo , K.E. , Anderton, A. and Milligan, K.A. (1995) . Airborne mycoflora in a hospital environment. Int. J. Environ. Health Res. 5:223-228.

Aronson, I.K. and Soltani, K. (1976). Chronic mucocutaneous candidias. Mycopathologia, 60: 17-25.

Atayese, A. O., Effedua, H. I., Oritogun, K. S. , Kareem K. T. and Ogunledun A. (2010). Comparative Study of the Antimicrobial Activity of Chlorinated and Non-chlorinated Antiseptics against C. albicans. Academia Arena. 2(9).

Azizi-far, M., Kazemi-fard H., Jandaghi GhR. and Safdari M., (2006). The study of dermatophytic infections in public swimming pools of Qom city during 2004. Rah. Dan. J. Arak Uni.Med. Sci., 3(9): 67-72.

Bello, O., Mabekoje, O., Egberongbe, O. and Bello, K.(2012). Microbial Qualities of Swimming Pools in Lagos, Nigeria. Int. J.App. Sci. and Tech. 2(8):89-96.

Bianchi, P., Repetto, A., Bulletti, S., Mattiacci, P., Rossi, J., Pagiotti, R.,Ribaldi, M. and Schiaffella, F. (1989). In vitro study of the antifungal activity of two chlorine derivatives to be used in antisepsis. Ann. Ig. ;1(3-4):827-40.

Cannon, P. F. and Hawksworth, D. L. (1995). The Diversity of Fungi Associated with Vascular Plants: the known, the unknown and the need to bridge knowledge gap. Adv. in Pla. Sci. 11: 277302 . 
de Hoog, G.S. and Guarro, J. (1995). Atlas of clinical fungi. Centraalbureau Schimmelcultures, The Netherlands and Universitat Rovira in Virgili, Spain.

Ellis, D.H. (1994) Clinical mycology. The human opportunistic mycosis. Pfzor. New York 166 pp.

Ellis, D., Davis, S. Alexrou, H., Handke, R. and Bartly, R.(2007). Description of medical fungi. Adeleide, Australia.

Fraise, A. P (2002) Biocide abuse and antimicrobial resistance-a cause for concern? J. Antimicrob. Chemother. 49:11-12.

Hawksworth, D. L. (1991). The fungal dimension of biodiversity: magnitude, significance, and conservation. Mycolo.Reas. 95: 641-655.

Hoseinzadeh, E., Mohammady, F., Shokouhi, R., Ghiasian, S. A., Roshanaie, G., Toolabi, A. and Azizi, S. (2013). Evaluation of biological and physico-chemical quality of public swimming pools, Hamadan (Iran). Int. J. Env. Health. Eng., 2(1), 21.

Itah, A. Y. and Ekpombok, M. U. E. (2004). Pollution status of swimming pools in south-south zone of south-eastern Nigeria using microbiological and physicochemical indices. Southeast Asian J. Trop. Med. Public Health, 35, 488- 493 .

Larone, D. (2011). Medically Important Fungi: A Guide to Identification. Ed. (5). Washington, DC: ASM Press.

Magaldi, S., Mata-Essayag, S., Hartung de Capriles, C., Perez, C., Colella, M.T., Olaizola, C., and Ontiveros, Y. (2004).
Well diffusion for antifungal susceptibility testing. Inter. J. Infec. Dis. 8:39-45.

Mohammad, T.H. and Habeb, K.A. (2014). Epidemiological Study of Keratinophilic Fungi in Baghdad Swimming Pools. J. B. f. S.11(3).

Nanbakhsh, H., Diba, K., and Hazarti, K. (2004). Study of fungal contamination of indoor public swimming pools. Iran. J. Pub. Heal. 33(1), 60-65.

Odds F., (1988). (2nd ed). Candida and Candidiasis. Baillière Tindall.

Papadopoulou, C., Economou, V., Sakkas, H., Gousia, P., Giannakopoulos, X., Dontorou, C., and Leveidiotou, S. (2008). Microbiological quality of indoor and outdoor swimming pools in Greece: investigation of the antibiotic resistance of the bacterial isolates. Int. J. Hyg. Environ., 211, 385-397.

Robins, C. and Morell, J. (2007). Mold Housing and Wood. In: Western Wood Products Association.

Viegas, C., Alves, C, Carolino, E., Pinheiro, C., Rosado, L. and Santos, C.S.(2011). Assessment of fungal contamination in a group of Lisbon's Gymnasiums with a swimming Pool. Ita. J. Occup. Env. Hyg. 2(1):15 - 20.

Viegas, C., Alves, C., Carolino, E., Rosado, L. and Silva Santos, C. (2010). Prevalence of fungi in indoor air with reference to gymnasiums with swimming pools. Ind. Bu.env. 19(5):555561 .

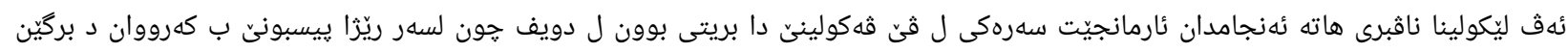

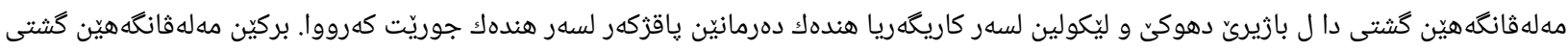

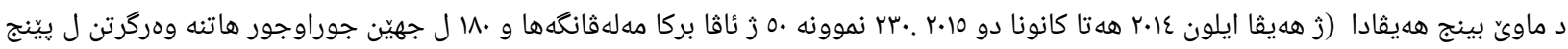

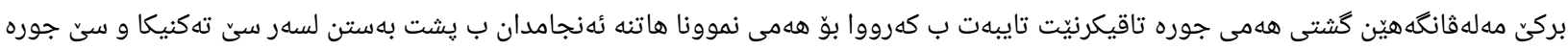

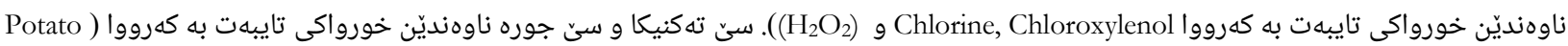
و و Dextrose Agar, Malt Extract Agar

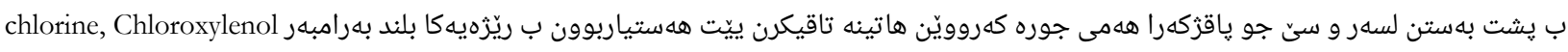

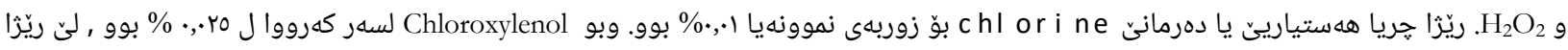

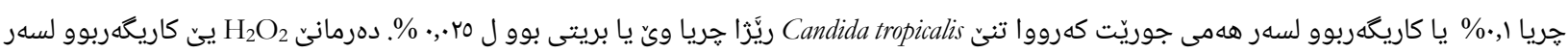

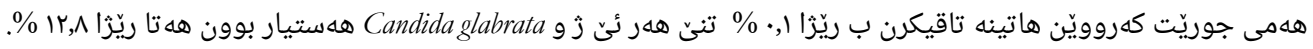

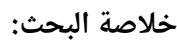
أجريت الدراسة الحالية لدراسة مستوى تلوث الخمائر في احواض السباحة العامة المغلقة في مدينة دهوك. تم جمع •بr عينة (عينات المياه .0) مأخوذة من

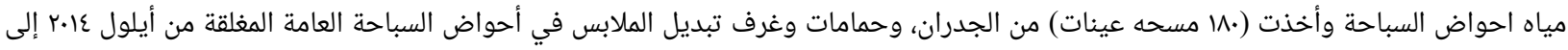

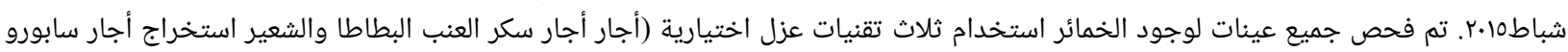

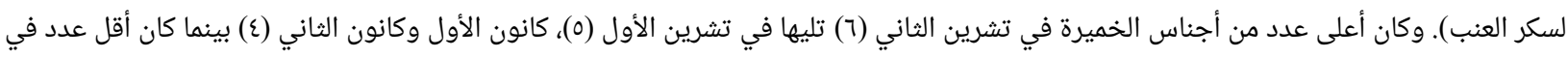

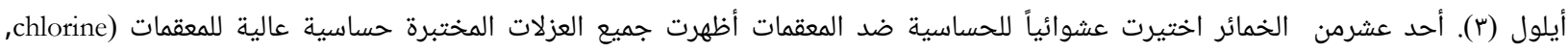

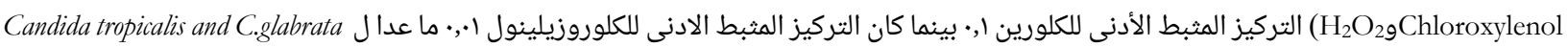
، بينما للمعقم الاخير تراوحت بين ا,• الى ^رrاب\%. 